\title{
Rancang Bangun Sistem Sensor Serat Optik untuk mengukur Ketinggian Cairan secara Kontinyu
}

\author{
Achul Mukmin* dan Agus Rubiyanto \\ Jurusan Fisika-FMIPA, Institut Teknologi Sepuluh Nopember \\ Kampus ITS Sukolilo, Surabaya 61111
}

Intisari

\begin{abstract}
Telah dilakukan eksperimen rancang bangun sistem sensor serat optik untuk mengukur ketinggian (Level) cairan secara kontinyu, memanfaatkan perubahan intensitas cahaya akibat perubahan indeks bias air dan udara yang terdeteksi pada ujung serat optik. Eksperimen menggunakan metode sederhana terdiri dari rangkaian pemancar berupa LED infra merah $(880 \mathrm{~nm})$. Serat optik moda jamak step indek dari bahan PPMA (Polymethyl Metacrylate), rangkaian penerima berupa fotodioda (OPT 101), multimeter digital dan PC. Jaket serat optik dikupas sepanjang $180 \mathrm{~cm}$ dan dibersihkan menggunakan larutan aseton, selanjutnya digunakan sebagai probe sensor berbentuk $U$ dengan diameter lengkungan $28 \mathrm{~cm}$. Data hasil eksperimen berupa grafik dan database dalam excel, menunjukkan performansi sensor mampu mendeteksi perubahan ketinggian dengan jangkauan $800 \mathrm{~mm}$, daerah kerja sensor $80-490 \mathrm{~mm}$, sensitivitas $1,5 \mu \mathrm{V} / \mathrm{mm}$ dan resolusi perubahan ketinggian setiap kenaikan $6 \mathrm{~mm}$.
\end{abstract}

KATA KUNCI: sensor ketinggian serat optik, liquid-level sensor

\section{PENDAHULUAN}

Penggunaan sensor serat optik adalah salah satu cara pengukuran ketinggian cairan dalam tangki yang hanya membutuhkan sumber cahaya dan serat optik, yang berinteraksi dengan zat cair. Sehingga aman dan bebas dari korosi, tanpa bunga api listrik yang dapat menyebabkan kebakaran atau ledakan. Selain sensitif, akurat dan repeatable (berulang), cahaya selalu terpandu dalam serat optik sehingga intensitas cahaya tetap dari satu ujung ke ujung serat optik yang lain [1].

Eksperimen rancang bangun sensor serat optik moda jamak step indeks untuk mengukur ketinggian permukaan zat cair secara kontinyu diharapkan memberikan manfaat dalam pengembangan serat optik sebagai sensor ketinggian untuk mengukur ketinggian permukaan zat cair secara kontinyu, yang dapat dimanfaatkan untuk mendeteksi perubahan tinggi permukaan cairan seperti cairan kimia, cairan yang mudah terbakar, air.

Aplikasi serat optik sebagai sensor ketinggian pendeteksi perubahan ketinggian permukaan zat cair telah banyak digunakan. Beberapa aplikasi lebih banyak dalam pengukuran ketinggian secara diskrit[2-4]. Sedangkan beberapa aplikasi yang lain memungkinkan pengukuran ketinggian secara kontinyu[1, 5, 6]. Prinsip pengukuran didasarkan pada perbedaan intensitas cahaya yang masuk melalui pangkal serat optik terhadap cahaya yang keluar dari ujung serat optik. Perubahan ini disebabkan perbedaan indeks bias zat cair dan udara akibat perubahan ketinggian permukaan air.

\footnotetext{
*E-MAIL: achul09@mhs.physics.its.ac.id
}

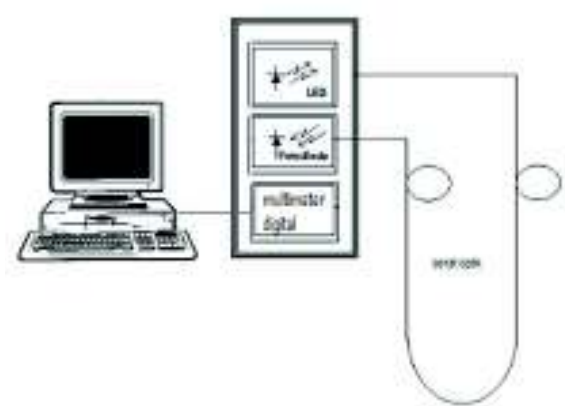

Gambar 1: Skema eksperimen sensor ketinggian serat optik

Pada rancang bangun sensor ketinggian serat optik, menggunakan metode lebih sederhana, terdiri dari sumber cahaya LED dan fotodetektor untuk mengukur ketinggian permukaan zat cair $[1,7]$.

\section{METODOLOGI PENELITIAN}

Sistem optik dalam sensor ini ditunjukkan pada Gambar 1, yang terdiri dari rangkaian pemancar, rangkaian penerima, serat optik, multimeter digital dan komputer.

\section{Pembuatan Probe Sensor Serat Optik}

Dalam rancang bangun sensor ketinggian serat optik ini digunakan serat optik plastik berbahan PPMA (Polymethyl Metacrylate), dengan diamater inti $950 \mu \mathrm{m}$ dan ketebalan cladding $50 \mu \mathrm{m}$, sehingga diamater serat optik keseluruhan 


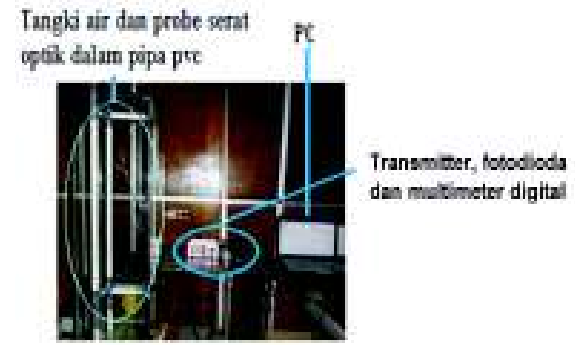

Gambar 2: Set up eksperimen

adalah $1000 \mu \mathrm{m}$ [8]. Indek bias inti 1,492 dari bahan PMMA dan indek bias cladding 1,417 dari bahan polimer terfluorisasi, dengan nilai numerical aperture $(\mathrm{NA})=0,47$.

Panjang serat optik yang digunakan sebagai probe sepanjang 2 meter, salah satu ujungnya dilengkapi konektor yang dihubungkan ke detektor fotodioda. Sedangkan ujung yang lain tanpa konektor dihubungkan pada sumber cahaya berupa LED infra merah.

Pembuatan probe sensor ketinggian serat optik dilakukan dengan cara menyayat satu sisi jaket dengan posisi cutter horisontal agar tidak melukai inti serat optik; melepas jaket yang telah terbuka sebagian, dengan tangan hingga jaket terlepas; melakukan etsa kimia serat optik tanpa jaket menggunakan larutan aseton, hingga cladding terlepas; untuk pengamatan lebih teliti hasil etsa cladding serta optik, dilakukan dengan menggunakan mikroskop pembesaran 40 kali; memasang probe sensor serat optik pada pipa pvc untuk mengurangi cahaya luar dengan lengkungan $28 \mathrm{~cm}$.

\section{Prinsip Kerja Sensor ketinggian Serat Optik}

Setup eksperimen ditunjukkan Gambar 2, pangkal serat optik dihubungkan dengan konektor pemancar (LED infra merah), ujung serat optik dihubungkan dengan konektor penerima (fotodioda) OPT 101 yang mempunyai respon spektrum 200-1100 nm dan puncak respon $880 \mathrm{~nm}$.

Keluaran penerima berupa tegangan dibaca Multimeter digital PC 510, 5000 Count/Bar Graph RS-232C dan sudah terkoneksi dengan PC yang terinstall software PC-link untuk dibaca komputer dalam dua bentuk, yaitu bentuk grafik sebagai tegangan fungsi waktu dan database yang terekam dalam microsoft excel. Data yang terekam selanjutnya dikonversi dalam grafik fungsi tegangan terhadap ketinggian zat cair. Data hasil konversi selanjutnya digunakan untuk mengkarakterisasi sensor ketinggian serat optik, meliputi fungsi transfer, zero offset, sensitivity, linieritas [9].

\section{HASIL DAN PEMBAHASAN}

Sensor ketinggian serat optik adalah sensor pendeteksi perubahan ketinggian/tinggi permukaan cairan dengan memanfaatkan serat optik sebagai komponen penting pendeteksi perubahan ketinggian permukaan cairan. Prinsip kerja dari sensor serat optik ini memanfaatkan pelemahan (atenuasi) daya,

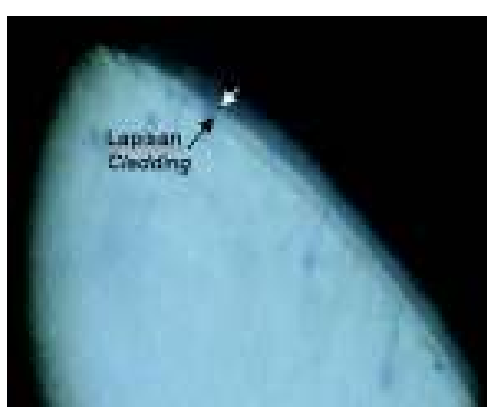

Gambar 3: Hasil rekam fotografi penampang melintang serat optik tanpa jaket

akibat rugi-rugi daya yang disebabkan oleh perbedaan indeks bias udara dan cairan, selanjutnya udara dan cairan berfungsi sebagai cladding, ditunjukkan Gambar 3.

Daya mengalami perubahan akibat indeks bias yang mengelilingi serat optik tanpa jaket dan cladding. Semakin tinggi serat optik yang dikelilingi air maka semakin tinggi daya yang dihasilkan, karena indeks bias air lebih besar daripada udara. Pada keadaan kosong maka serat optik dikelilingi udara sehingga rugi-rugi daya menyeluruh, setelah terisi air sebagian dikelilingi air yang berfungsi sebagai cladding dan mempunyai rugi-rugi daya yang semakin berkurang. Pada saat air memenuhi seluruh serat optik, maka rugi-rugi daya semakin kecil dan daya yang dihasilkan semakin besar, karena seluruh cahaya mengalami pemantulan dan evanescent oleh air $[6,7,10,11]$. Semakin tinggi inti serat optik yang dikelilingi air, maka semakin besar nilai tegangan yang terukur oleh PC. Cahaya paling kuat terjadi pada rugi daya paling kecil dan absorpsi paling kecil, apabila permukaan air menutup seluruh serat optik tanpa cladding.

\section{Hasil Pengujian Probe Sensor}

Hasil uji probe serat optik dilakukan dengan mengamati dan melakukan rekam fotografi penampang melintang perbesaran 40 kali untuk serat optik yang telah dikupas jaketnya, menunjukkan lapisan cladding dan inti serat optik, ditunjukkan pada Gambar 3.

Hasil uji probe serat optik dilakukan dengan mengamati dan melakukan rekam fotografi penampang melintang perbesaran 40 kali untuk serat optik yang telah dibersihkan claddingnya, menunjukkan inti serat optik saja, cladding tidak teramati setelah dietsa, ditunjukkan pada Gambar 4.

\section{Hasil Pengujian sistem sensor Optik}

Rancang bangun sensor ketinggian serat optik untuk mengukur tinggi permukaan zat cair secara kontinyu telah dilakukan. Data hasil pengukuran yang dihasilkan adalah data hasil pengukuran oleh software multimeter digital yang telah terinstal dalam PC, berupa grafik hubungan tegangan terhadap waktu (Gambar 5) dan data dalam format excel terdiri dari waktu pengukuran dan tegangan. Gambar 5 menunjukkan 


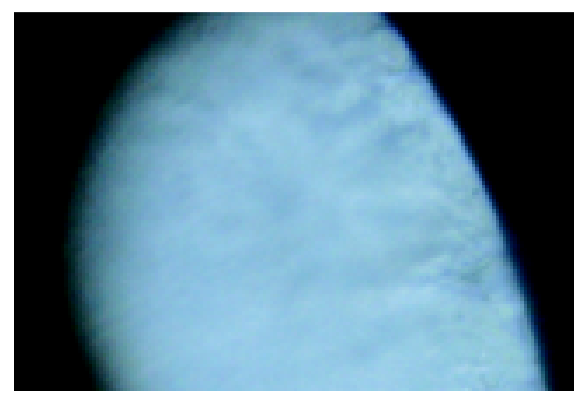

Gambar 4: Hasil rekam fotografi penampang melintang serat optik hasil etsa

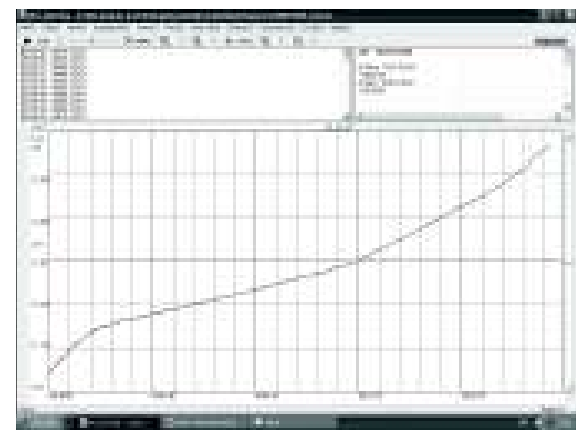

Gambar 5: Tampilan software pengambilan data

hubungan tegangan fungsi waktu hasil pengukuran sensor ketinggian serat optik. Data hasil pengukuran dilakukan dalam waktu 13 menit 50 detik dengan 1856 data tegangan, tinggi permukaan yang diamati $800 \mathrm{~mm}$.

Untuk mengetahui hubungan dari data hasil pengukuran berupa perubahan tegangan terhadap perubahan waktu dan perubahan tegangan terhadap perubahan ketinggian permukaan air. Data hasil eksperimen selanjutnya di konversi menjadi data tegangan fungsi ketinggian permukaan air, ditunjukkan oleh grafik pada Gambar 6.

Dari data perubahan tegangan terhadap perubahan waktu yang telah dikonversi menjadi data perubahan tegangan terhadap perubahan tinggi permukaan air, pada Gambar 6. Pada tinggi permukaan 0-80 $\mathrm{mm}$ masih terpengaruh lengkungan serat optik, sehingga setiap kenaikan ketinggian, posisi inti

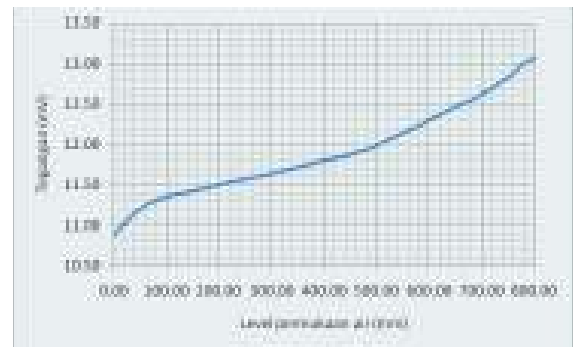

Gambar 6: Grafik Hasil konversi Hubungan Tegangan dan ketinggian permukaan air

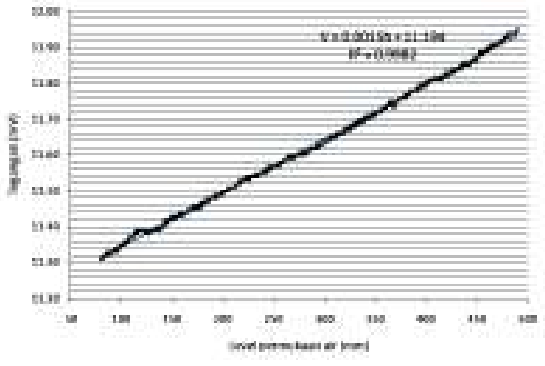

Gambar 7: Grafik linier tegangan fungsi ketinggian permukaan air $800-490 \mathrm{~mm}$

serat optik yang melengkung lebih banyak yang dikelilingi air dan tegangan yang dihasilkan lebih cepat mengalami perubahan. Pada ketinggian permukaan 80-490 mm menunjukkan kenaikan tegangan yang linier terhadap kenaikan permukaan air dan posisi serat optik pada ketinggian ini relatif lurus. Dan pada ketinggian lebih dari $490-550 \mathrm{~mm}$ inti serat optik mengalami sentuhan dengan pipa PVC dan pada tinggi 550-800 $\mathrm{mm}$, kondisi serat optik melengkung. Kondisi serat optik yang tidak lurus menyebabkan bagian yang terendam lebih banyak pada setiap kenaikan ketinggian yang sama.

Hasil regresi linier pada ketinggian permukaan air 80-490 $\mathrm{mm}$, diperoleh persamaan $\mathrm{V}=0,0015 \mathrm{~h}+11,194$, standar deviasi $0,17 \mathrm{~mm}$ dan hasil uji linieritas menghasilkan nilai, nilai ini mendekati, sehingga hubungan antara tegangan terhadap perubahan ketinggian permukaan air pada daerah yang dipilih adalah linier.

\section{Pembahasan}

Cahaya LED yang merambat dalam serat optik menyebabkan terjadinya perbedaan intensitas setelah keluar dari serat optik, ketika serat optik tanpa cladding dikelilingi oleh air dan belum dikelilingi air. Air berfungsi sebagai cladding, karena cladding pabrikan telah dihilangkan. Pantulan internal sempurna terjadi pada permukaan inti- air. Cahaya mencapai fotodioda dengan rugi daya dibandingkan serat optik yang masih utuh. Ketika tangki terisi tidak penuh, sebagian dari serat dikelilingi air dan sebagian lain dikelilingi udara. Di bagian yang terendam air pantulan internal sempurna terjadi karena serat mempunyai cladding air, tetapi pada serat yang dikelilingi udara tidak terjadi pantulan internal sempurna, sebagian besar cahaya mengalami rugi daya. Sehingga, semakin tinggi air yang mengelilingi serat optik maka semakin besar intensitas yang keluar dari ujung serat optik yang diterima detektor.

Hasil eksperimen sebelumnya sensor ketinggian serat optik mampu mendeteksi ketinggian permukaan air setiap kenaikan $2 \mathrm{~cm}$. Jangkauan $16 \mathrm{~cm}$ [4]. Dari hasil yang diperoleh pada eksperimen dan karakterisasi sensor ketinggian serat optik, sensor serat optik ini mempunyai performansi sebagai sensor ketinggian dengan kemampuan orde lebih kecil, untuk mendeteksi kenaikan permukaan air dengan parameter sensor yang ditunjukkan pada Tabel 1. 
TABEL I: Parameter Sensor Serat Optik Sebagai Sensor ketinggian

\begin{tabular}{ll}
\hline \hline Parameter & Sensor ketinggian \\
\hline Daya sumber & $95 \mathrm{~mW}$ \\
Resolusi perubahan ketinggian & $6 \mathrm{~mm}$ \\
Jangkauan (Span) & $800 \mathrm{~mm}$ \\
Daerah Kerja & $80-490 \mathrm{~mm}$ \\
Sensitivitas & $1,5 \mu \mathrm{V} / \mathrm{mm}$ \\
\hline \hline
\end{tabular}

Parameter serat optik sebagai sensor ketinggian serat optik berupa resolusi perubahan ketinggian, jangkauan, daerah kerja dan sensitivitas masih dapat ditingkatkan dengan pembuatan konstruksi probe yang lebih stabil. Performansi sensor ketinggian dapat ditingkatkan menggunakan serat optik berdiameter lebih besar, lebih panjang, menambah diameter kelengkungan probe menjadi lebih besar untuk mengurangi rugi-rugi daya akibat lengkungan. Mengatur probe serat op- tik hanya kontak dengan air dan posisi harus lurus. Sehingga air merendam penampang probe serat optik sama untuk setiap kenaikan ketinggian yang sama.

\section{SIMPULAN}

Dari eksperimen rancang bangun sistem sensor serat optik untuk mengukur ketinggian air secara kontinyu disimpulkan bahwa sistem sensor serat optik menunjukkan bahwa, pada tinggi permukaan 80-490 mm menunjukkan kenaikan tegangan yang linier, diperoleh data karakterisasi sistem sensor ketinggian serat optik dengan fungsi transfer $y=0,0015 x+$ 11,207 , daya sumber $95 \mathrm{~mW}$, resolusi perubahan ketinggian $6 \mathrm{~mm}$, jangkauan (Span) $800 \mathrm{~mm}$, daerah kerja 80-490 mm, sensitivitas $1,8 \mu \mathrm{V} / \mathrm{mm}$.
[1] Prez-Ocn, F., Rubino, M., Abril, J.M., Casanova, P., Martinez, J.A. , Sensors and Actuator, A125, hal. 124-132 (2006)

[2] Musayev, E., and Karlik, S.E., Sensors and Actuators, A 109, hal 21-24(2003).

[3] Nath, P., Datta, P., Sarma, K.C., Microwave and Optical Technology Letters, Vol. 50, No. 7, hal 1982-1984 (2007).

[4] Artanadi, Wayan, Desain Sistem Sensor Level Cairan dengan fiber optik FD 620-10, Tugas Akhir, ITS, Surabaya, 2008.

[5] Golnabi, H. , Optics and Lasers in Engineering, Vol. 41, hal. 801-812(2004).

[6] Prez-Ocn, F., Rubino, M., Abril, J.M., Casanova, P., Martinez, J.A.,Sensors and Actuator, A125, hal. 124-132 (2006).

[7] Ilev, I.K. and Waynant R.W., Review of Scientific Instruments,
Vol. 70, hal. 2551-2554 (2009).

[8] Samian, Pramono, Y.H., Rohedi, A.Y., Yudoyono, G., Jurnal Fisika dan Aplikasinya, Vol. 4, No. 2, hal. 08020310802035(2008).

[9] Fraden, J., Handbook of Modern Sensors (3rd edition, SpringerVerlag, Inc., New York, 2004).

[10] Yin, S., Ruffin, P.B., Yu, F.T.S., Fiber Optic Bio and Chemical Sensors, dalam Fiber Optics Sensors, eds. Yin, S., Ruffin, P.B., Yu, F.T.S., Taylor and Francis Group, New York.hal 436-487, 2008.

[11] Golnabi, H., Bahar, M., Razani, M., Abrishami, M., Asadpour, A., Optics and Lasers Engineering, Vol. 45, hal 12-18 (2007). 